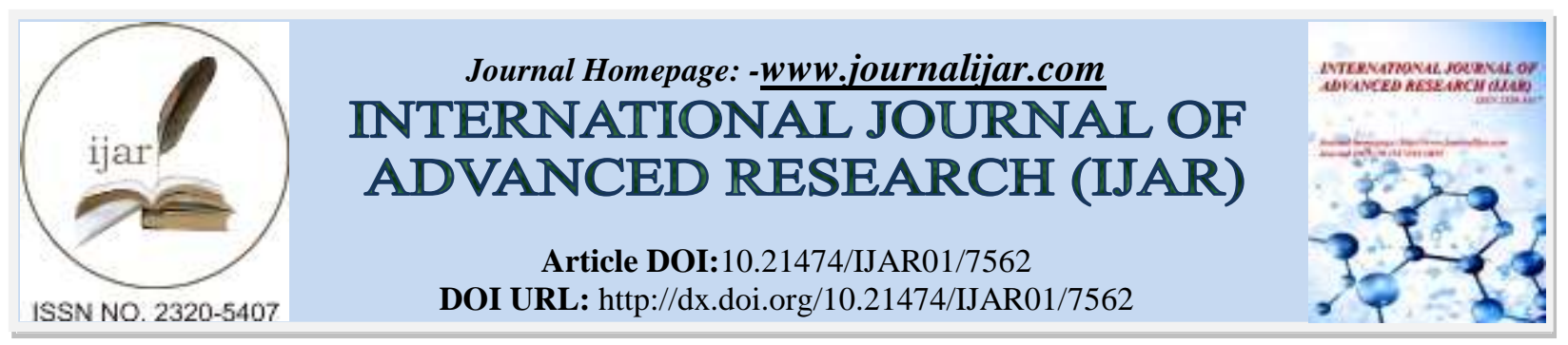

RESEARCH ARTICLE

\title{
DETECTION OF IgG ANTIBODIES AGAINST HYDATID CYST DISEASE IN HUMAN SERUM BY ELISA.
}

Manhal H.Salman, Shadha Abud.Algabar and Salamya E.Salman.

\section{Manuscript Info}

\section{Manuscript History}

Received: 14 June 2018

Final Accepted: 16 July 2018

Published: August 2018

\section{Abstract}

Echinococcosis is a zoonotic infection caused by developmental stages (larvae, hydiatid,metacetodes) of two kinds of tapeworms, Echinococcus granulosus and Echinococcus multilocularis, Sources of infection are final hosts (i.e. dogs for E. granulosus and mainly foxes for E. multilocularis) and food contaminated with parasite eggs. After oral ingestion of parasite eggs by humans (intermediate hosts) and hematogenous distribution inside the host, E. granulosus larvae (oncospheres) begin to vesiculate mainly in the liver and lungs and in other organs. The difficulty and the similarity of clinical symptoms with other diseases, the disease is diagnosed Serological ways including ELISA test.82 serum samples collected from some hospitals in Baghdad randomly. To detect the Human Hydatid Cyst disease non-visible symptoms in humans and used the ELISA test. results showed $18.29 \%$ positive case.

Copy Right, IJAR, 2018,. All rights reserved.

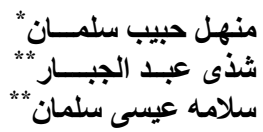

الخلاصه

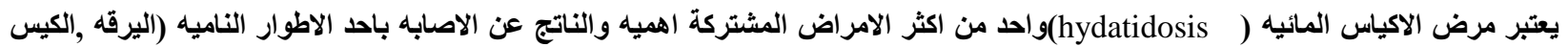

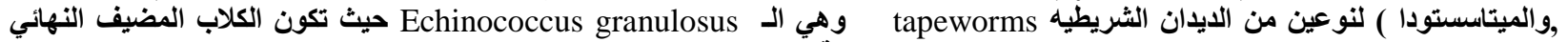

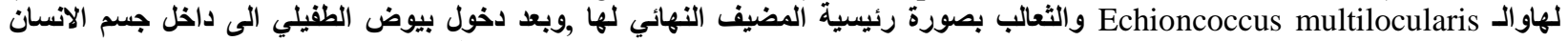

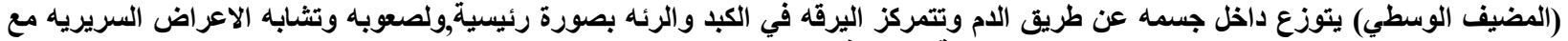

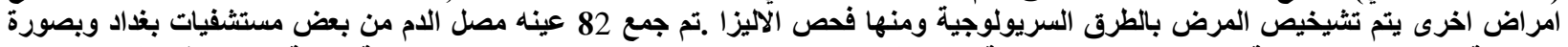

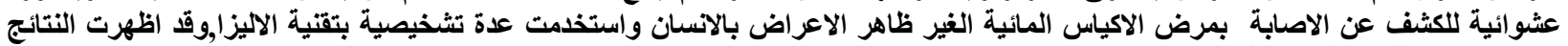

\% 18.29 نسبة اصابة موجبة الاصفية. 
يعتبر مرض الأكياس المائية من الأمراض المعدية والمتسبية عن الاصابة بأحد المراحل التطورية (larvae, hydatid, metacestodes) لنوعين

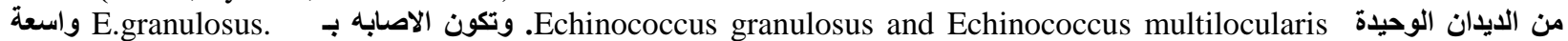

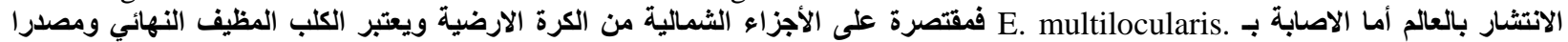

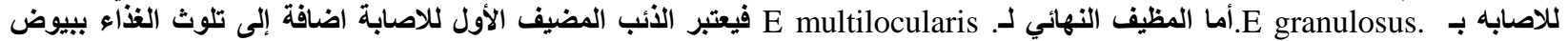

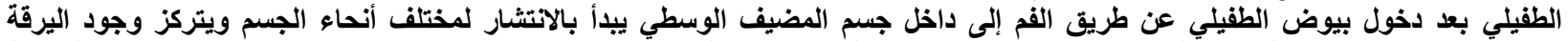
(Encospheres)

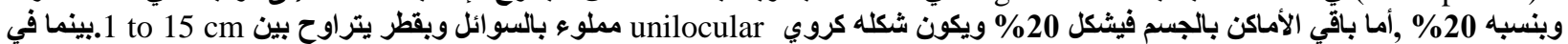

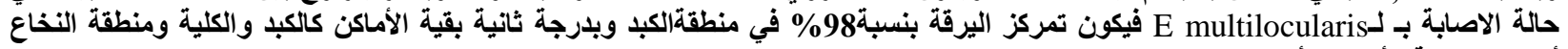

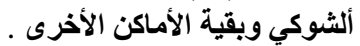

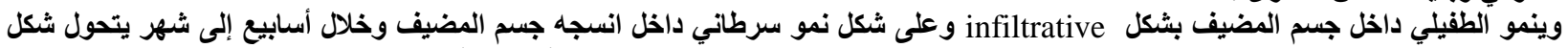

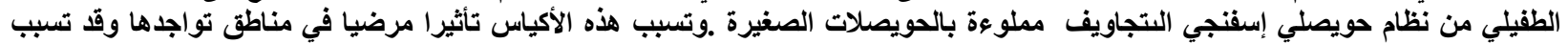
عطل في عمل الانسجه الحيوية للمضيف او الاوعيه أو لاعضاء الجسم والأعراض المرضية نتيجة الاصابه تختلف حسب حجم وموقع الكيس أما يكون

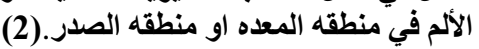

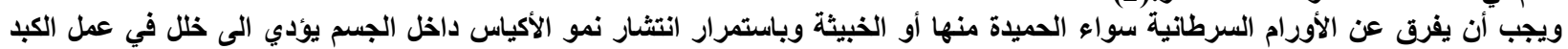

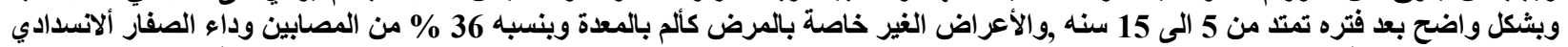

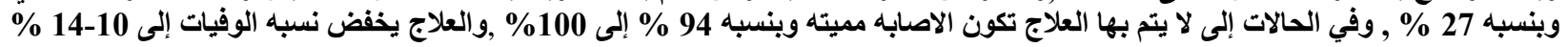

$(4,2)$.

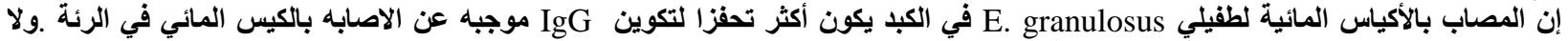

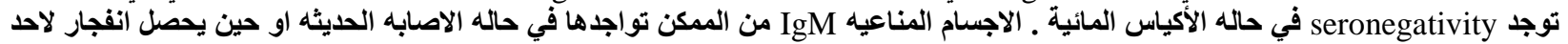

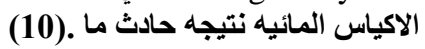

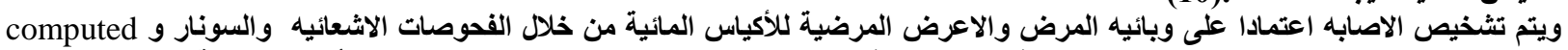

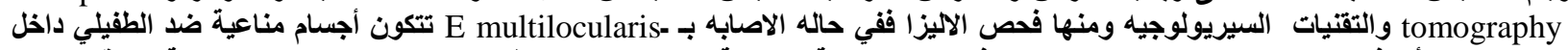

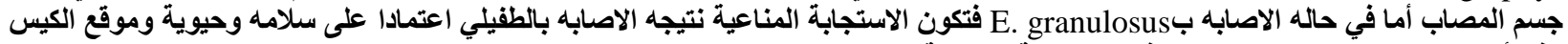

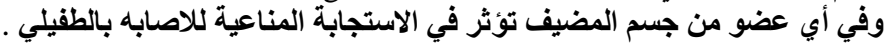

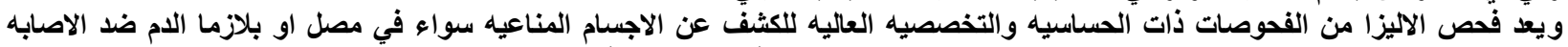

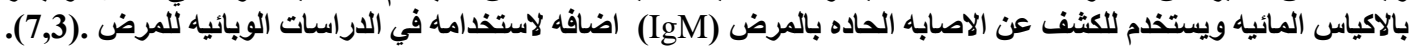

المواد وطرائق البحث

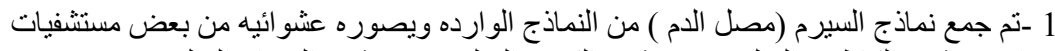

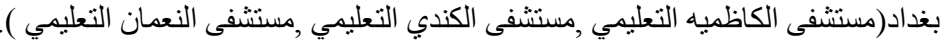

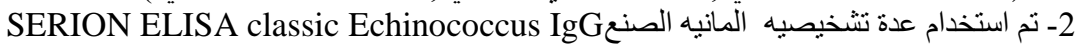

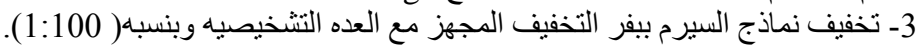

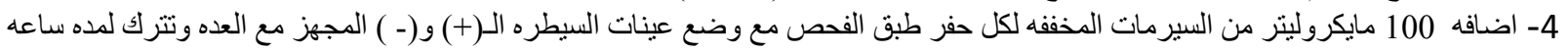

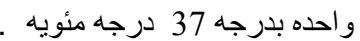
5- غسل طبق الفحص بمحلول دربه الغسل المجهز مع عدة الفحص وبكميه 300 مايكروليتر للتخلص من المواد الز ائده و الغير مرتبطه بالطبق.

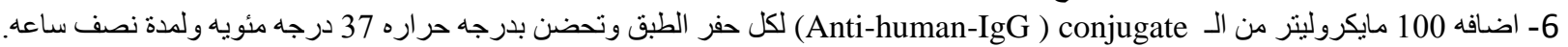
7- اعادة الخطوه رقم 5 .

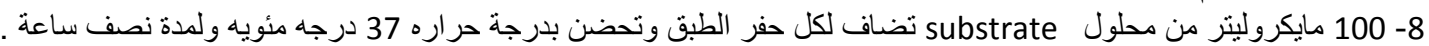

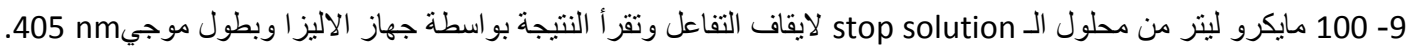

النتائج

اظهر الفصص لـ82 عينه مصل الام ان نسبه الاصابه 18.29\% وقد توزعت الاصابات كما موضح في الجدول رقم (1)

\begin{tabular}{|c|c|c|c|}
\hline Samplelhospital & positive (+) موجبة (+) & & النسبه المئويه \\
\hline مستشفى الكاظميه & 9 & 32 & 21.95 \\
\hline مستشفى الكندي & 2 & 11 & 15.38 \\
\hline مستشفىى النعمان & 4 & 24 & 14.28 \\
\hline 82 & 15 & 67 & 18.29 \\
\hline
\end{tabular}

المناقشه 


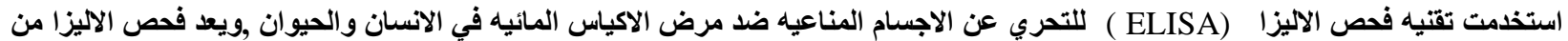

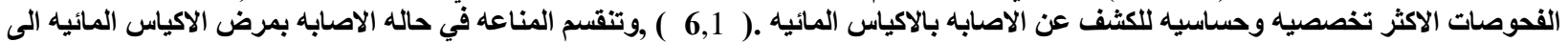

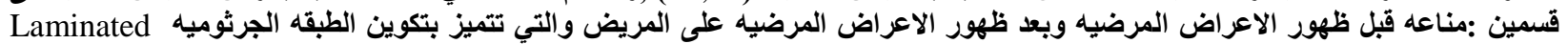
لإيلو Layer حول الكيس المائي والتى تظهر مابين الاسبوع الثاني التى الاسبوع الرابع بعد الاصابه في المضيف الوسطي او الأنسان بعد عمليه ابتلاعه

للبيوض وافراز ال(Oncosphere)

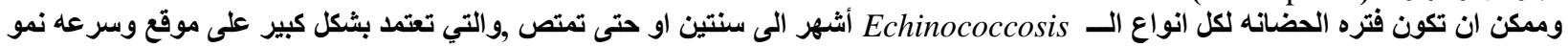

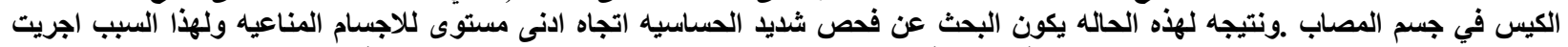

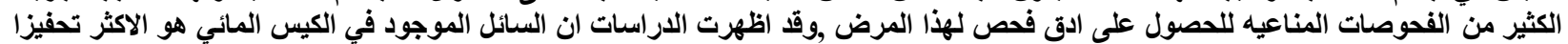

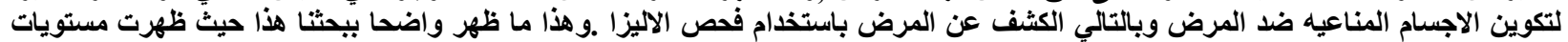

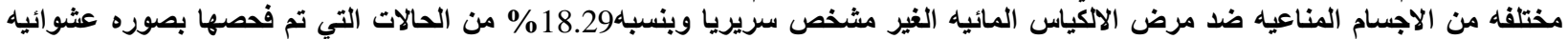

.$(9,8,5)$.

ـتبليغ الجهات الصحية ذات العلاقة بجعل فحص التحري عن الاجسام المناعية ضد مرض الاكياس المائية الغير ظاهر الاعراض ضمن التوصيات :

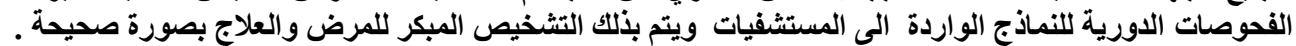

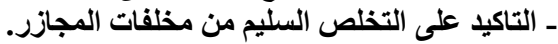
ـ الاستمرار بحملات الاباده للكلاب السائبه .

\section{References:-}

1. Biava, M.F.,Dao,A.,Fortier,B.,(2001)Laboratory Diagnosis of Cystic Hydatic Disease.World J.Surg.Jan;25(1):104.

2. Craig,Ps,Rogan,MTandCampos-Ponce,M(2003).Echinococcosis:disease,detectionand transmission,Parasilology.(suppl).127:25-s20. Gottestein, B (1984).An immunoassay for the detection of circulating antigens in human echinococcosis ,Am.J.Trop.Med.Hyg.,33:1105-1109.

3. G.r.Hashemi Tabar,A.Haghparast and H.Borji(2010).Serodiagnosis of Sheep Hydatidosis with Hydatid Fluid,Protoscolex and Whole Body of Echinococcus granulosus Antigens.W.A.S.J :9(7)788-792.

4. Gottstein,B.,(1992).Molecular and immunological diagnosis of cystic of echinococcosis.Clin.Microbiol.Rev.5(3),243-261.

5. Hashemitabar, G. R.1*; Razmi, G. and Shahroozian, A. R.(2008). Application of a modified human enzymelinked immunosorbent assay kit for diagnosis of hydatidosis in sheep . I.J.V.R.Vol.9,No.1,Ser.No.23.

6. Lightowlers,M.W.,Liu,D,Haralambous A and Rickard.M.D.(1989).Subunit composition and specificity of the major cyst fluid anntiaens of Echinococcus granulosus.Molecular Biochemical Parasitology ,37:171-182.

7. Ortona,E,R.Rigano,B.Buttari,F.Delunardo,S.cloppolo,p.Margutti,E.Profumo,A.Teggi,S.

8. Vaccari and A.Siracusano,(2003).An update on immunodignosis of cystic ehinococcosis.Acta.Trop, 85:165171.

9. Pedro,L.,Moro,H.Hector,E Garcia Armando,.E.Gonzales,J.Juan,Bonilla Manuela,H.Verastegui Robert and M.D.Gilman,(2005).Screening for cystic echinococcosis in an endemic region of Peru Using Portable Ultrasonography and the Enzyme-Linked Immunoelectro Transfer blot (ETTB) assay parasitol Res.,96:242246.

10. Seyed M.Sadjjadi,Farzaneh Sedaghat,Seyed Vahid Hosseini, and Bahador Sarkari(2010).Serum Antigen and Antibody Detection in Echinococcosis:Application in Serodiagnosis of Human Hydatidsis.W.A.S.J.Vol.9 No.7.

11. S.A.Luka,I.Ajogi,I.Nock,C.Kudia and J.Umoh.(2009).Evaluation of Enzyme -Linked Immunosorbent Assay (ELISA) and Western Blotting for the immunodiagnosis of hydatid diseases in Sheep and Goats.J.V.M.:V.5 .N.2. 